\title{
The Discourse of Meaning of Jihad in Muhammadiyah Circle (A Hermeneutics Perspective)
}

\author{
Said Romadlan \\ Universitas Muhammadiyah Prof. Dr. HAMKA \\ Mahasiswa Program Doktor Departemen Ilmu Komunikasi, Universitas Indonesia \\ author correspondence : saidromadlan@uhamka.ac.id
}

DOI: https://doi.org/10.18196/jkm.112028

Article Info

Article history:

Received 09 Oct 2019

Revised 21 Oct 2019

Accepted 13 Nov 2019

\begin{abstract}
This study focuses on the discourse about the meaning of Jihad that emerged in the Muhammadiyah circle as one of the Islamic Organizations in Indonesia. The discussion of meaning of Jihad as a way of peace or a way of war becomes crucial amid radicalism, terrorism, violence movements and chaos waged on behalf of religion. However, Muhammadiyah believes that the meaning of Jihad is anti-war and anti-violence which strengthens the understanding of Islam as the religion of rahmatan lil alamin (a mercy to all creation). This belief is criticism and contra-discourse towards camps that perceive Jihad as war and acts of violence. This study uses Paul Ricoeur's Interpretation Theory and focuses on the interpretation of the text based on the distinction between the text and the reader. The method is Ricoeur's hermeneutic method which focuses on the distortion of language, discourse, and textuality. The study shows that textually the meaning of Jihad among the Muhammadiyah circle is jihad lil-muwajahah, or the struggle to tackle a challenge by creating a superior movement, for example, "Jihad Konstitusi." Muhammadiyah's understanding of the meaning of Jihad can be used as a counter-discourse on the meaning of Jihad which well known as an act of terrorism.
\end{abstract}

Keywords: discourse; jihad; Muhammadiyah; hermeneutic; ricoeur.

\begin{abstract}
ABSTRAK
Artikel ini menitikberatkan pada diskursus yang muncul di kalangan Muhammadiyah sebagai Organisasi Islam berkemajuan mengenai jihad. Diskursus mengenai makna jihad sebagai jalan damai atau jalan perang menjadi penting di tengah menguatnya gerakan-gerakan radikalisme, tindakan terorisme dan kekerasan atas nama agama. Di sisi yang lain, pemahaman Muhammadiyah terhadap makna jihad sebagai anti-perang dan anti-kekerasan menjadi penguat pemahaman Islam sebagai agama rahmatan lil alamin. Pemahaman ini sekaligus juga menjadi kontra-diskursus dan kritik terhadap diskursus-diskursus yang memahami jihad sebagai peperangan dan tindakan kekerasan. Kajian ini menggunakan teori Interpretasi Paul Ricoeur yang salah satunya memfokuskan pada penafsiran atas teks berdasarkan penjarakan (distansiasi) antara teks dengan pembaca. Adapun metodenya adalah metode hermeneutika Ricoeur yang menitikberatkan pada distansiasi bahasa, diskursus, dan tekstualitas. Hasil kajian menunjukkan bahwa secara tekstual diskursus makna jihad di kalangan Muhammadiyah adalah jihad lil muwajahah, yakni perjuangan menghadapi sesuatu dengan cara menciptakan sesuatu yang unggul, salah satu bentuknya adalah jihad konstitusi. Pemahaman atas makna jihad Muhammadiyah ini dapat dijadikan sebagai kontra-diskursus atas makna jihad yang selama ini dominan, yakni jihad sebagai tindakan terorisme.
\end{abstract}

Kata Kunci: Diskursus, Jihad, Muhammadiyah, Hermeneutika, Ricoeur 


\section{INTRODUCTION}

After September 11th, 2001's incident and the war against terrorism's propaganda initiated by the President of United States George W. Bush, Jihad seems to be the foundation of terrorist acts all over the world. War against terrorism's propaganda has resurged the nationalism and solidarity of many Islamic members in many countries. The reason is the feeling of unity and solidarity among Islamic members in confronting the West attack. September 11th became the legitimacy or justification for acts executed by Islamic radicals, including Jihad and other anti-West movements (Nathan and Kamali, 2005).

Some bombing and shooting taking place in European countries and Indonesia indicate that Jihad as a justification of terrorism is being stronger. An explosion and gunfire in Paris, France, on November 13rd 2015, were one of the examples of terrorism acts which was arranged by ISIS (Islamic State of Iraq and Syria) and resulted in 132 fatalities and 350 injuries. Before that incident, there was also an act of terror in France, attacking Charlie Hebdo Magazine Office on January 7th 2015, which killed 12 people, and ISIS declared to be responsible for that (Majalah Tempo, November 23rd-29th 2015). On March 22nd, 2016 there was another bombing terror in Zaventem Airport and Metro Maelbeek Station, Brussels, Belgia. This morning attack killed 30 people, and ISIS admitted that they are the culprit of this attack (Majalah Tempo, March 28thApril 3rd, 2016). The regrettable incident also happened in Indonesia, which was then widely known as Thamrin Bomb. It killed 8 people, which 4 of them were the terror actors, and injured 27 people (Tempo, January 18th-24th, 2016). This Thamrin Bomb terror was suspiciously arranged by Bahrun Naim, an ISIS figure in South East Asia region in attempting to strengthen ISIS's influence in South East Asia (Majalah Tempo, January 25th-31st 2016).

Based on Bahrun Naim's confession or statement, ISIS was the group responsible for the shooting and bombing occurrence. ISIS was a group of terrorist which genealogically could be traced from the development of al-Qaeda in Iraq after the collapse of Saddam Husein in 2003. The founding father, Abu Musab al-Zarqawi, pledged an oath (Bai'at) to Osama bin Laden and made his group a part of al-Qaeda (AQI). Subsequently, Al-Zarqawi changed the AQI name into ISIS (Hikam, 2016; Ali, 2014). Although there are some differences in how they view Syi'ah, in the context, ISIS as a radical group had no disagreement with its central organization, al-Qaeda. ISIS adheres ideology platform of al-Qaeda and provokes that Jihad is a fight against the United States of America, Jewish, and their allies (Ali, 2014). Therefore, such terror actions executed by ISIS, which are autonomously performed in some countries, can be seen as their actualization of comprehending Jihad as terrorist acts,

The understanding of Jihad as a war (harb) towards the enemies of Islam, which is embraced by the Islamic radical groups like al-Qaeda and ISIS, is fundamentally one of the interpretations of al-Qur'an's verses concerning Jihad. From the perspective of radical groups, Jihad is a war (harb) and fight (qital), whereas, basically, Jihad is different from those two (Azra, 2016; Darras, 2017). Jihad is fighting against carnality (Azra, 2016), or, as understood recently, an endeavor to spread amar ma'ruf nahi munkar (encouraging goodness, preventing badness) in all aspects of life (Chirzin, 2017).

Jihad is derived from jahada that means endeavoring. Literally, Jihad means a maximal and robust effort to fight against the wrong (Azra, 2016). Jihad also has other meanings like hard opposition and resistance, resolving tasks or problems outright, sincere efforts to achieve goals, resisting poor conditions, and protecting someone's existence and life (Asymawi, 2002).

As for Jihad as a discourse, Jihad as the al-Qur'an verse is interpreted variously with various understanding and different contexts. The definition of Jihad being influential until now, including changing radicalism movement in Indonesia, comes from Hasan al-Banna, a founding father of Ikhwanul Muslimin (IM). Hasan al-Banna disdain, even attacks, the definition of Jihad as solely a spiritual struggle and effort against self-carnality (Azra, 2016). Likewise, Sayyid Quthub, another influential thinker, holds that Jihad is a political and revolutionary battle planned to disarm Islam enemies. Jihad aims to establish Islamic hegemony and liberate individuals and groups from nonmuslim's political domination (Azra, 2016). A more extreme perspective presented by Al Maududi (1980) that refute that Jihad is merely for defensive purpose. Jihad is a struggle that must be committed by a Muslim to manifest the Islamic ideal as an international revolutionary movement. Its purpose is to dismiss and usurp the oppressive and exploitative political force. 
That understanding of Jihad is manifested by al-Qaeda and ISIS, and other Islamic radical organizations, including some Islamic radical organization in Indonesia like Majelis Mujahidin Indonesia (MMI), Islamic Defender Front (FPI), Hizbut Tahrir Indonesia (HTI), Laskar Jihad (LJ), and Jamaah Islamiyah (JI) (Boy, 2009; Mubarak, 2007). Those organizations are categorized as radical because at least of two aspects, their movement affiliation and their world view. MMI, JI, and LJ are strongly assumed to correlate with al-Qaeda (Boy, 2009; Hasan, 2008; Ali, 2014). According to these radical groups, particularly al-Qaeda, Jihad means an act of terror and war against the United States of America and its allies. The understanding of al-Qaeda and other Islamic radical groups toward Jihad is a new kind of terrorism which do not include negotiation in their dictionary (Roy, 2004). This al-Qaeda's understanding of Jihad has Islam be a global phenomenon (Devji, 2005).

Furthermore, Hizbut Tahrir Indonesia (HTI) is categorized as a radical group, even though it does not wage terrorist acts. The reason is that it affiliates with International Hizbut Tahrir, which was established by Taqiy al-Din al-Nabhani in Pakistan in 1953 and aimed to re-establish Daulah Islamiah or Darul Islam, a state that implements Islamic laws. In the view of Hizbut Tahrir, a land that does not enforce Islamic laws is darul kufur. In Indonesia, HTI aspires to establish khilafah Islamiyah by substituting governmental system into khilafah and replacing Pancasila as the state's ideology with Islamic laws (shari'a) since Pancasila is considered kufur, and not appropriate to Islam (Arif, 2018). HTI was an endorser of first Congress of Majelis Mujahidin Indonesia in Yogyakarta in 2000 which presented Abu Bakar Ba'asyir as Amirul Mujahidin (Mubarak, 2007). On the other side, HTI is portrayed as a part of Islamic resurrection in Indonesia because of its extensive influence, notably in campus circles. However, HTI was dismissed by the Indonesia government in July 2017 (Santoso and Sjuchro, 2019).

Another organization is Islamic Defenders Front (FPI), which was considered a genuine Islamic radical group in Indonesia. This organization was declared in Ciputat, South Jakarta, in 1998. The leading figure of FPI is Habib Rizieq Shihab. As to the doctrine, FPI is relatively moderate compared to other Islamic groups that have an international affiliation. Nevertheless, in its action, with the "amar ma'ruf nahi munkar" paradigm, FPI is somewhat confrontational and tends to use violence in exterminating any disobedience. Jihad, according to FPI, is devastating infringed places that violate Islamic rules. In the political context, FPI used to release a political fatwa of the prohibition of a female president (Mubarak, 2007).

Some factors affect the understanding of meaning and act of Jihad. For instance, Al-Qaeda contends that Jihad is not only an effort to adhere to al-Qur'an's orders but also as antiglobalization and anti-imperialism movement. Therefore, Jihad is closer to Marxism than to alQur'an (Roy, 2004). Jihad that is conceived in its radicalism forms (Mubarak, 2007) is not only triggered by national interest but also religious ideas that are fallaciously defined, fanaticism, hopeless, and indignity felt by Islamic community because of the global injustice (Sirozi, 2005). In line with Sirozi's opinion, Moeslim Abdurrahman (2005) opined that the meaning of Jihad has been pirated by some Islamic communities which live in the past and fulfill with the feeling defeated and sad owing to West capitalism hegemony. Since Islam as world view must be assertive and distinct, problems approaching are made concisely simple. Consequently, Jihad is comprehended by any means (including by violence) to purify this very impure world from the oppressive hegemony of West.

According to Esposito (1992), Muslim radical groups that commit to terrorism in the name of Jihad are a product of the conspiracy of superpower neo-colonialism and Zionism, which is supported directly or indirectly by non-Islamic regimes. Militant movements, Khaled Abou al-Fadl said, in interpreting al-Qur'an's verses, they are too literal and ahistorical. As a result, the conclusion is strongly exclusive. Hence, this kind of interpretation needs symbolic actions that can differ explicitly between Muslim and non-Muslim. This analysis does not consider the sociological and historical contexts so that it overlooks the meaning outside of al-Qur'an texts (Mubarak, 2007).

Against that background, which accentuates the individuals' view of Jihad, this study intends to study one of the Indonesian moderate Islamic organizations, namely Muhammadiyah, in interpreting the meaning of Jihad. This study also proposes the interpretative factor or the understanding towards al-Qur'an verses (texts) as one of the factors which influence radicalism acts, aside from the other factors like the resistance on globalization and imperialism. This study is significant because the result of the study can be used as contra-discourse and ideological critics 
towards the common understanding of Jihad as terrorism. Besides, the factor of Muhammadiyah as a moderate Islam organization in Indonesia becomes a proponent and advocate of the dissemination of Jihad, which is non-violence and rahmatan lil alamin (Rahman, 2014). It is wellknown that Muhammadiyah is an Indonesian Islamic modernist organization based on urban society (Azra, 2005). Muhammadiyah is also identified as moderate Islam movement (washiliyah) that gives priority to peacefulness (Boy, 2009; Nashir, 2014). Therefore, the question which will be addressed in this study is how is the discourse of Jihad in Muhammadiyah circle as moderate Islam organization?

The term 'discourse' is popularized by Michel Foucault. Discourse is a totality of domains in which language is used in specific manners. In the context, it is all conceptual domains where knowledge is constructed or constituted and generated (Lubis, 2014). Discourse is divided into two areas. First, discourse is comprehended in the context of the study of language as social acts and interactions, where people interact with each other in the real social situation. Second, discourse is widely used in the social theory of post-structuralism that understands it as the construction of social reality and form of knowledge (Fairclough, 1995; 2010). Paul Ricoeur (2016) defines discourse hermeneutically to comprehend texts. Text is a discourse that is standardized through writing. Therefore, discourse is always related to the use of language. Indeed, Ricoeur refers to language as an event; language which explains something.

This study uses the Interpretation theory of Paul Ricoeur. The Interpretation theory -or in the term of Littlejohn named as Interpretive Theory - refers to the theory and analysis perspective in many fields, ranging from communication, sociology, anthropology, education, cultural study, political science, history, to humanities. Interpretive Theory can be defined as a research tool that ontologically and epistemologically focuses on understanding how individuals and groups produce meaning in their daily routine, communication, and life experiences.

Ricoeur's Interpretation Theory focuses on text as a written work that owns certain autonomy. It can be perceived as a kind of reading which response to the independence of text by simultaneously describing the element of understanding (verstehen) and explanation (erklaren) and incorporating both into a process of interpretation. In the realm of hermeneutics, interpretation is a primary problem that can be defined in two ways; first, it is related to the aspect of implementation, and second, it is linked to the element of epistemology. Concerning its implementation, interpretation exists because of the availability of the text; the written text, and its autonomy. 'Autonomy' means the independence of text from the author. Another aspect is epistemology, which implies the concept of interpretation is opposed noticeably to the concept of explanation.

There are three attempts exercised by Ricoeur in elaborating on his hermeneutics and concept of interpretation theory. First, Ricoeur tries to bridge the contraposition between Betti's hermeneutics of tradition and philosophical hermeneutics of Gadamer through phenomenological hermeneutics (Belicher, 1980). Second, Ricoeur attempts to find an intersection among hermeneutics sects, particularly between philosophical hermeneutics of Gadamer and Habermas's critics of ideology. Ricoeur intends to make hermeneutics as a critic of ideology towards any interest which distorts discourse. Third, Ricoeur aims to overcome the classical problem of hermeneutics contradicting comprehension (verstehen) and explanation (erklaren) by rendering both as a dialectics that correspond one another (Ricoeur, 2006).

One of the unique concepts of Ricoeur's Interpretation Theory is the relation between text, act, and ideology. An act, precisely a meaningful act, can be positioned as a text that can be interpreted by anyone. An act is a primordial base of ideology phenomena. According to Ricoeur (Thompson, 2003), ideology is associated with an image that is absorbed by a specific social community, and it is a self-representation of a community that owns history and identity. Thus, ideology can provide implicit comprehension in act moments, which is located in the genealogy of community or group. The fundamental function of ideology is a mediation and unity tool to consolidate, tighten, and integrate all members of the group.

Ricoeur's view on ideology can be apprehended through three kinds of concepts. First, ideology as a meaningful act. The emergence of this ideology corresponds to the need of a group to create certain self-image, to represent, and actualize itself. Second, ideology functions as real manipulation and distortion if it is related to its general function, namely integration, and its specific function, domination. Third, ideology is associated with the concept of distortion or about the alteration of form through 'deformation.' In any human ideologies, the condition appears 
inverse, like in Obscura camera. In this context, ideology is determined by its function and content; if there is a deformation, it is because human creation happens inverse too. Within this context, the content of ideology is a religion, which is not only an example of ideology but also the ideology itself. Ideology is a mistake that compels us to exchange reality with image and authentic with reflection.

Studies concerning Ricoeur's Theory of Interpretation have been done by many scholars, and one of which is Louise Hardwick (2016) from the Department of Sociology, Social Policy, and Criminology, The University of Liverpool, Liverpool, UK. In his article entitled Paul Ricoeur's Theory of Interpretation Adapted as a Method for Narrative Analysis to Capture the Existential Realities Expressed in Story from People Living with Multiple Sclerosis, Hardwick explained how Ricoeur's Theory of Interpretation is applied as a method, through narrative analysis, to grasp reality expressed by the life of multi sclerosis people. This adaptation can make multi sclerosis people's experience to be better.

The other research is done by Glenda Ballantyne (2014) from Sociology, Swinburne, University of Technology, Hawthorn Victoria, Australia, which discusses the implementation of Ricoeur's hermeneutics in the sector of pedagogic, academic language and learning practice. In his article entitled Conversing with Subjects: Applying Paul Ricoeur's Hermeneutics to Pedagogical and Academic Language and Learning Practice, Ballantyne uttered that inclusive dialogue, mutual acceptance, and sensitivity become a crucial aspect in the learning process of academic language. Ricoeur's hermeneutics can form those aspects.

The uniqueness of this study compared to other studies is on the interpreted text. In this study, the interpreted text exists in al-Qur'an language or verses. Through the distinction process, the meaning of al-Qur'an in the form of language becomes autonomous on the level discourse and textuality. By this way of interpreting, it can result in the new understandings which are more contextual. This is different from the previous research that emphasizes the interpretation of people's acts (Hardwick, 2016). Besides, the aim of this study is pretty distinct, which is more critical than the previous studies, which are more practical, such as for learning (Ballantyne, 2014). This study stresses the attempt of how the results of an understanding process can be made as contra-discourse toward today's understanding of Jihad that inclines to be war and terrorism.

\section{METHOD}

This study used a hermeneutic method. It is an approach that fundamentally deems the relations to perceive and interpret texts and theological texts. The primary notion of hermeneutics in analyzing a text is disassociating the meaning of the text from the author's perspectives (Bryman, 2008). In the field of communication, hermeneutics becomes one of the new paradigms as an alternative for the transmission paradigm, an old standard that has long been dominant (Radford, 2005). As a new paradigm, hermeneutics emphasizes (1) the implementation of interpretation method, (2) deconstruction method (radical hermeneutics), (3) science as networking, (4) a specific and local thing, and (5) language and interpretation (Lubis, 2014).

The data collection was performed through (1) collecting documents that correspond to the problems of Jihad via Muktamar decisions, Tanwir, official news of Muhammadiyah, and Suara Muhammadiyah Magazine, during a month from January to March 2018, (2) in-depth interview about Jihad with Muhammadiyah figures, and (3) literature study by finding related references about Jihad.

The subject of this study was Muhammadiyah organization. It is a people organization established by KH. Ahmad Dahlan in 1912 in Yogyakarta. Muhammadiyah is an Islamic movement that preaches about the importance of amar ma'ruf nahi munkar and tajdid, which are based on al-Qur'an and Sunnah. Furthermore, Muhammadiyah applies Islam as its organizing principle. The intentions and aims of Muhammadiyah are to maintain and upholding Islam so that a truly Islamic society is manifested. The main character of Muhammadiyah is an Islamic movement that commits on dakwah and tajdid through a dynamic and advanced organizational system (Nashir, 2006).

According to Azyumardi Azra (Nathan and Kamali, 2015), Muhammadiyah is a modernist Islamic organization and a salafi movement, which encourages the purification of Islamic orders, exposes Ijtihad door and adapts a modern organizational approach through education, health, and social services. In addition, Muhammadiyah can be categorized as a modern Muslim organization that possesses a solid basis in urban territory. 


\section{RESULT AND DISCUSSION}

The focus of Ricoeur's hermeneutics analysis is to find the autonomy of text or the independence of text towards the author's intention. Typically, it is called distantiation.

Based on the decision of the Muktamar of 100th years Muhammadiyah at the 46th Muktamar 2010 in Yogyakarta, referring to the Thought Statement of Muhammadiyah, it was uttered that Muhammadiyah manifests and actualizes Jihad as an endeavor by exerting anything that they are capable of (badlul juhdi) to realize prosperous, dignified, and sovereign lives for all mankind. Muhammadiyah understands Jihad, not as a struggle by violence, conflict, and hostility. By contrast, Muhammadiyah's understanding of Jihad relied on surah Al Hujurat verse 15, which observed: "The believers are only the ones who have believed in Allah and His Messenger and then doubt not but strive with their properties and their lives in the cause of Allah. It is those who are the truthful."

The understanding of Muhammadiyah on Jihad can be described hermeneutically by text analysis as follow:

a. Explanation (Erklaren): analyzing text by in-depth semantic, including:

1) Background: a part of the text that explains the background of the text to comprehend the aim of text creation.

Muhammadiyah's understanding of Jihad without violence is inextricable from Muhammadiyah's commitment to developing the perspective and mission of progressive Islam continuously. As it has been stated in the Second Century Thought Statement of Muhammadiyah at 46th Muktamar 2010 in Yogyakarta as follow:

"A progressive Islamic perspective aims to breed enlightenment for life. Enlightenment (tanwir) as the form of progressive Islam is an Islamic way to liberate, empower, and advance life from any kind of backwardness, oppression, stagnation, and injustice of human's life."

2) Detail: a part of the text that describes the importance of text by presenting a text that benefits the author more:

Muhammadiyah's comprehension about Jihad that emphasizes more on strengthening the endeavor to exert ones' capacity or competence (budlul juhdi) to manifest the prosperous, dignified, and sovereign lives of all mankind is the manifestation of Muhammadiyah's notion of progressive Islam. A progressive or advanced Islam plant the seeds of truth, goodness, peace, justice, benefit, prosperity, and virtue of living dynamically for all humanity. It is a kind of Islam that upholds the dignity of humans both male and female, without discrimination. Those ideas are stated in the Second Century Thought Statement of Muhammadiyan at 46th Muktamar 2010 in Yogyakarta as follow:

"A progressive Islam is an Islam that acknowledges the mission of anti-war, antiterrorism, anti-violence, anti-oppression, anti-injustice, and anti towards all forms of destruction in this world such as corruption, abuse of power, humanity crime, nature exploitation, and various kinds of badness that destroy live. Islam positively emerges virtues which cover the diversity of ethnic groups, races, fractions, and human culture on earth."

3) Intention: a part of the text that elucidates the author's purpose by deciphering the text explicitly.

Adhering to ulama's opinion, Muhammadiyah understands Jihad as not only fight with non-Muslim but also struggling for the enhancement of Islam itself. Therefore, Jihad can be in the form of wealth, soul, energy, and thought. Building the facilities of education and operating it, constructing the facilities of transportation, and even obeying parent's orders can be named Jihad. According to Prof. Muh. Zuhri, an officer of Fatwa Division of MTT PWM Central Java, in his article entitled "Jihad Perang dan Jihad Damai" (War Jihad and Peaceful Jihad) that was published in www.suaramuhammadiyah.id (17/04/2016), he stated that:

"To struggle in Islam requires seriousness, tenacity, and sincerity, providing soul, wealth, and thought. In the religious term, it is called Jihad. The purpose of Jihad is nothing but achieving a peaceful and prosperous life in Allah's way. This is because 
da'wah fundamentally must represent sympathy, so that peaceful Jihad becomes a basis of struggle. Dakwah should not be too energetic not to put violence before peace."

4) Assumption: a part of the text that elaborates the meaning of the text by presenting valid and true statements.

Jihad, in the Muhammadiyah's perspective, is not a struggle of violence, conflict, and hostility. It has been uttered in the Second Century Thought Statement of Muhammadiyah at 46th Muktamar 2010 in Yogyakarta as follows:

"To face the complexity of life's problems and challenges, members of Islam are required to apply strategy modification from the fight against something (al-jihad lilmuaradhah) to struggle for something (al-jihad lil-al-muwajahah) in the form of providing best alternative solutions to manifest more virtue life."

One of the forms of jihad lil-muwajahah implemented by Muhammadiyah is "constitutional Jihad' through judicial review." It was co-manifested by Muhammadiyah, civil society, and some national figures. The Decision Tanfidz of the 47th Muktamar of Muhammadiyah in 2015 stated that:

"Muhammadiyah, together with civil society and some nation's figures, undertake a judicial review for some laws that cause constitutional disadvantage for Indonesian society and endanger the sovereignty of the state. A judicial review is undertaken by Muhammadiyah as a national responsibility to maintain a nation's sovereignty and achieve the national goals of independence."

b. Understanding or interpretation (Verstehen): interpreting a text by an in-depth interview that involves:

1) Distantiation: the detachment of the substance of text from the author's intent.

Prof. Muh. Zuhri, an officer of Fatwa Division of MTT PWM Central Java, stated that Jihad means a total struggle, and with high spirit, to defend the enforcement of Allah's orders. Because it is defined as a total struggle, Jihad is frequently understood and actualized in the form of war, widely known as jihad fi sabilillah (struggling in Allah's way).

Muhammadiyah as a progressive Islamic organization, as it has been inscribed in the Second Century Thought Statement of Muhammadiyah at 46th Muktamar 2010 in Yogyakarta, interprets and actualizes Jihad as an endeavor to use any capacity or competence (badlul juhdi) to create advanced prosperous, dignified, and sovereign humans lives. Muhammadiyah's perspective on Jihad is not a struggle using violence, conflict, and hostility. This Muhammadiyah perspective relies on surah Al-Hujurat verse 15, which means as follows: "The believers are only the ones who have believed in Allah and His Messenger and then doubt not but strive with their properties and their lives in the cause of Allah. It is those who are truthful."

Concerning distantiation, the understanding process of Muhammadiyah towards the meaning of Jihad can be described through the process of distantiation below:

Distantiation 1: language as a discourse where the term "jihad (jihadu)" (struggling seriously) --as it has been inscribed in surah al Hujarat verse 15-is interpreted by Muhammad as preaching (dawah) amar ma'ruf nahyi munkar (engaging goodness and preventing badness). Dakwah is an activity that invites people to recognize Islam thoroughly with sympathy and not horrific. Jihad, as dawah, persuades people to perform goodness and prevent badness. Islam, therefore, should be presented as it is, a peaceful, soothing, and appeased, and not by terror, threat, violence, and anarchism.

Distantiation 2: discourse becomes a text (textuality) in which the discourse on Jihad as dakwah amar ma'ruf nahyi munkar is comprehended textually by Muhammadiyah as a struggle for something (al-jihad lil-al-muwajahah) in the form of providing the best alternative answers to create a better life. It has been inscribed explicitly in the Second Century of Thought Statement of Muhammadiyah at 46th Muktamar 2010 in Yogyakarta as below:

"To face the complexity of life's problems and challenges, members of Islam are required to apply strategy modification from the fight against something (al-jihad lil- 
muaradhah) to struggle for something (al-jihad lil-al-muwajahah) in the form of providing best alternative solutions to manifest more virtue life."

The process of distantiation of Muhammadiyah's comprehension of Jihad can be briefly conceived as follow:

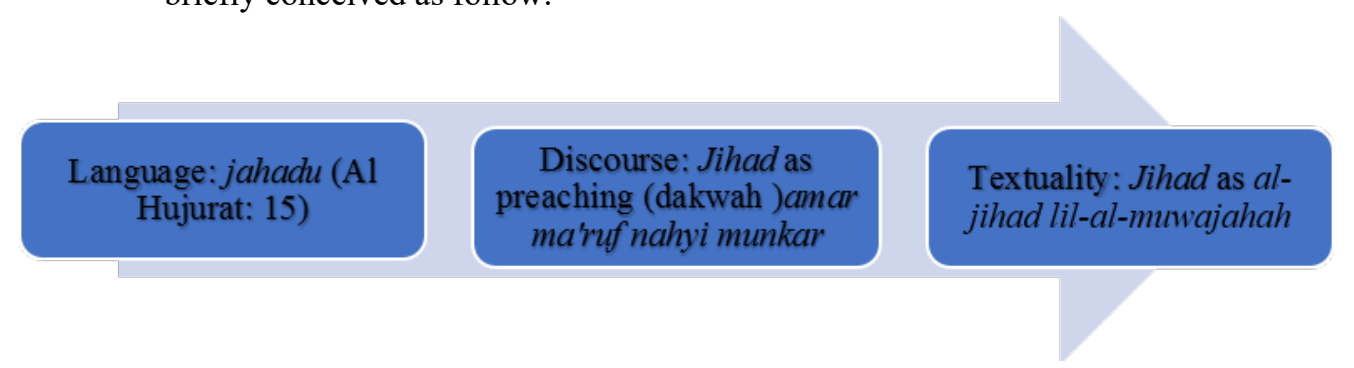

Figure 1. The distantiation process of Muhammadiyah's comprehension of Jihad

2) Reference or substance of text: this is not only to find the inscribed meaning beyond the text, but to comprehend the reality spread inside of text.

As an Islamic organization, Muhammadiyah interprets Jihad contextually as recorded in surah al-Hujarat verse 15. Contextually, the background of Muhammadiyah's comprehension of Jihad as a struggle for something (al-jihad lil-al-muwajadah) is the nowadays condition of Islamic members, Indonesia nation, and Muhammadiyah in dealing with the complexity of life's problems and challenges. On the article published in www.suaramuhammadiyah.id (01/07/2017) entitled "Haedar Nashir: Bergerak dari Jihad Lil-Muaradlah ke Jihad Lil-Muwajahah" (Haedar Nashir: Moving from Jihad Lil-Muaradlah to Jihad Lil-Muwajahah", Dr. Haedar Nashir, the chairperson of central committee of Muhammadiyah, stated that: "This is what Muhammadiyah refers to as the era of al-jihad lil-muwajahah, namely the struggle to earnestly build something superior as the best choice for things that are not wanted". Besides, in the Second Century of Thought Statement of Muhammadiyah at the 46th Muktamar 2010 in Yogyakarta uttered that: "Muhammadiyah's perspective on Jihad is not a struggle by violence, conflict, and hostility. Moslems are required to apply strategy modification from fight against something (al-jihad lil-muaradhah) to struggle for something (al-jihad lil-al-muwajahah) in the form of providing the best alternative solutions to manifest better life to face the complexity of life's problems and challenges."

3) Subjectivity (interpretation): Comprehending means revealing through the process of recognition of the world that has been offered and spread by interpretation.

At this level, Muhammadiyah's understanding of Jihad as a struggle for something (al-jihad lil-al-muwajahah) becomes a reflection and be admitted (recognition) as a movement and struggle that is aspired by Muhammadiyah as a progressive Islamic movement. One of the concrete forms of Muhammadiyah Jihad is the "constitutional Jihad' by doing a judicial review on laws that cause constitutional disadvantage for Indonesian society and endanger the state's sovereignty. Judicial review is performed by Muhammadiyah as the national responsibility to uphold the state's sovereignty and achieve national independence goals. This has been covered in the Decision of Tanfidz of the 47th Muhammadiyah Muktamar 2015 as follow:

"Many products of laws contradict the 1945 Constitution (UUD 1945). This happened because of the poor quality of legislators, law buying between rulers and foreign businessmen, and the lobbying of interest groups. Those strategic actions, for Muhammadiyah, are the implementation of constitutional Jihad to save Indonesia and the future generation of this nation as a whole part of enlightenment dawah to reach advanced or progressive Indonesia."

In addition, the hermeneutics analysis towards Muhammadiyah's comprehension on Jihad can be explained through hermeneutics model of Ricoeur (see figure 2) below: 
Explanation or Erkleren:

a. Background: Jihad without violence as the implementation of a perspective of progressive or advanced Islam.

b. Details: Jihad that emphasizes on the endeavour by exerting any capacity or competences available (budlul juhdi)

c. Intention: Jihad is a struggle to improve the condition of Islamic members.

d. Assumption: Jihad is a form of providing the best alternative solutions to create a better life (jihad lil muwajahah.
Comprehension or Interpretation (Verstehen):

a. Distantiation:

- Language: jihadu fi sabilillah (total efforts in Allah's way).

- Discourse: Jihad as preaching (dakwah) amar ma'ruf nahyi munkar.

- Textuality: Jihad is a form of providing the best alternative solutions to create a better life (jihad lil muwajahah).

b. Reference or substance of text: Understanding term jihad fi sabilillah as jihad lil muwajahah.

c. Subjectivity (Interpretation): Jihad fi sabilillah as jihad lil muwajahah is interpreted as a constitutional Jihad (judicial review).

Figure 2. The analysis of Ricoeur's hermeneutics towards the Muhammadiyah's comprehension of Jihad

Muhammadiyah, as a moderate Islamic organization, apprehends Jihad as jihad lil muwajahah (Jihad as a struggle for something). According to Haedar Nashir, the chairperson of central committee of Muhammadiyah, al-jihad li-al-muwajahah is an earnest struggle to create something superior as the best option for something that is wished (suaramuhammadiyah.com, 01/07/2017: 20.11). The understanding of Muhammadiyah on Jihad as jihad lil muwajahah was decided at the 46th Muhammadiyah Muktamar 2010 in Yogyakarta.

Muhammadiyah's comprehension of Jihad as jihad lil muwajahah, in the context of Ricoeur's theory of interpretation, can be discussed through two primary aspects. First, regarding Ricoeur's notion about the autonomy of text and distantiation among language, discourse, and textuality, and, second, as to Ricoeur's wish to make interpretation (hermeneutics) as critics of ideology towards hegemonic text comprehension through distantiation (text autonomy) and subjectivity of reader's interpretation.

Firstly, Muhammadiyah's comprehending of Jihad as jihad lil muwajahah is fundamentally an end understanding or reflection from interpretation or understanding process on text or term Jihad itself. Jihad, genealogically, comes from a word jahadu, which means an honest endeavor in the first process of distantiation, specifically when it becomes discourse. Moreover, it is apprehended as an earnest endeavor in preaching (dawah) amar ma'ruf nahi munkar (inviting people to do good and preventing badness). In the next process of distantiation, namely discourse process becomes textuality, the meaning of Jihad is not only understood by Muhammadiyah as preaching amar ma'ruf nahi munkar in the form of fight or war against something but as jihad lil muwajahah struggle for something by creating better and superior something.

The understanding of Muhammadiyah on Jihad through distantiation process in Ricoeur's theory of interpretation can be considered as a model or concept of new interpretation that emphasizes the "recognition" character (Ricoeur, 2006). Recognition is a text interpretation 
centralized on self-interpretation of the subject which then can apprehend him/herself better and different or at least start to understand him/herself ('concrete reflexion').

In this case, Muhammadiyah exercises recognition towards the meaning of Jihad as jihad lil muwajahah by spreading the meaning of Jihad not beyond the text but precisely in he text world itself, so that a new and recent meaning is found. The further meaning of Jihad is reflected and designed in the concrete actions of Muhammadiyah as a moderate Islamic organization by proposing goodness (ma'ruf). One of which is "constitutional Jihad" by doing a judicial review on some laws that cause constitutional disadvantage for Indonesian society and endanger state's sovereignty. Judicial review is performed by Muhammadiyah as the responsibility of nationality to uphold the state's sovereignty and achieve the national goals of independence.

Muhammadiyah's constitutional Jihad becomes such a reflection towards a subjective interpretation of Muhammadiyah on the meaning of Jihad. In the new theory of interpretation, comprehension of the text should not only end in the text, but there should be a bridge between text and subject (Muhammadiyah). Consequently, Muhammadiyah's comprehension of Jihad was codified (tahfidz) as one of the decisions of the 47th Muhammadiyah Muktamar 2015 in Makassar, South Sulawesi.

The understanding of Jihad as jihad lil-muwajahah is obviously different from the meaning of Jihad understood by Islamic radical groups. For example, FPI, although FPI relies on the same doctrine or paradigm -that is preaching amar ma'ruf nahi munkar-but on the level of implementation, it is considerably different. FPI exposes confrontational character and tends to put violence in exterminating badness. FPI's conception of Jihad is by destroying un-Islamic places. Muhammadiyah is different from FPI. Instead of demolishing "bad" places by violence, Muhammadiyah promote usefulness in preaching amar ma'ruf nahi munkar. Muhammadiyah establishes achievement and creates advantages in various aspects, particularly in the aspect of education and health. This is seriously the real meaning of Jihad apprehended by Muhammadiyah -Jihad as jihad lil-muwajahah.

On the other hand, HTI comprehends Jihad as effort to establish daulah Islamiyah (Islamic state) with its Khilafah system -a system which is understood by HTI as a phase to apply syari'ah or Islamic laws and intend to change the Ideology of Pancasila with Islam. On the contrary, Muhammadiyah precisely upholds the Unitary State of Republic of Indonesia (NKRI) by enacting Pancasila State as darul ahdi wa darus syahadah (Consensus State and Witness State). Pancasila is a consensus of Indonesian founding fathers and a locus of witness where Pancasila is maintained by the interests of Islam to advance this nation. This had been decided at the 47th Muhammadiyah Muktamar 2015 in Makassar. In this case, Muhammadiyah's conception on Jihad -that is maintaining Pancasila with something superior and progressive - is manifested.

This Muhammadiyah's comprehension of Jihad is different from Indonesia Islamic groups, which affiliate with al-Qaeda like Majelis Mujahidin Indonesia (MMI), Jamaah Islamiyah (JI), and Laskar Jihad (LJ). Their aims of Jihad exactly resist and fight against the United State of America and its allies through terrorist actions. It is highly dissimilar with Muhammadiyah that apprehends Jihad as jihad lil-muwajahah -that is producing achievements and excellences and cooperating with various elements, including the one that has a different religion. It had been asserted by Abdul Mu'thi, a general secretary of the central committee of Muhammadiyah, that: "Muhammadiyah can interact and even cooperate with adherents of any religion in an account of creating usefulness and goodness for all, and not exceeding the principles". (An interview with the author on November 16th, 2018 at Dakwah Building of Muhammadiyah, Menteng, Central Jakarta).

The understanding of the meaning of Jihad discoursed that is practiced by Muhammadiyah as a moderate Islamic organization becomes such contra-discourse or ever farther as contra-hegemonic towards acts that are stimulated by the interpretation of Jihad. Nowadays, the dominant understanding of Jihad is still Jihad as the acts of terrorism as it has been interpreted and exercised by al-Qaeda and other Islamic radical groups (Roy, 2004; Devji, 2005; Azra, 2015). By implementing the process of discourse about the proper meaning of Jihad which is done by the leaders and members of Muhammadiyah via various channels like social media, mass media, public communication in the form of recitation activities, the discourse of Jihad meaning will be more appropriate with the mission of Islam as a religion that preaches rahmatan lil alamin. According to Fanani (2004), by campaigning the image of Islam as a religion of peace and 
hospitable, the dark image of Islam, which is caused by a few Islamic adherents, can be averted or even abolished.

The discourse of the meaning of Jihad around the Muhammadiyah circle is in line with the wish of Ricoeur (2006) to make hermeneutics not just a tool of interpretation, but as critics of the dominant ideology. In this case, the dominant ideology is Jihad as acts of terrorism and radicalism. The critics of ideology that is applied by Muhammadiyah is through the subjectivity of interpretation towards the meaning of Jihad itself. In this context, Muhammadiyah comprehends Jihad as not acts of violence and terrorism, but as an earnest struggle for establishing and creating something superior. For Muhammadiyah, the meaning of Jihad is not put inside the inscribed text but spread in reality, in front of text, which may be different from the intention of the author.

\section{CONCLUSION}

Muhammadiyah as a progressive Islamic movement shoulders the responsibility to make Islam a hospitable religion, as well as presenting usefulness in this world. To reach that aim, Muhammadiyah must continuously provide enlightenment through the comprehensions of various Islamic issues, whether locally or globally. One of them is the problem of the meaning of Jihad often misled by Islamic radical groups as terrorism. In this case, Muhammadiyah and other moderate Islamic organizations like NU must continuously cooperate to produce the discourses of Jihad contextually and encourage peacefulness.

The existence of the comprehension of Jihad as terrorism is a phenomenon that cannot be eluded because the terrorists are the groups that represent themselves as Islamic groups that name their acts of terrorism as Jihad. Nevertheless, the factors that affect terrorism as Jihad are globalization and imperialism and not religious doctrines. However, comprehension of texts or verses related to Jihad is also significant because mistaken acts typically resulted from a misunderstanding of Jihad.

The implication of this study contributes to making concepts of Jihad more contextual and compatible with its nature, as it had been implemented by Muhammadiyah. Moreover, the idea of Jihad can be interpreted more broadly and variously according to their interests. In the implication of interpretation theory, this study contributes to answering the doubt of some people that, subjectively, the interpretation theory should not end on the level of text interpretation only but beyond it by making understanding as acts. The last point is related to the hermeneutics method. The implication of this study is -as Falahuddin suggested (Darras, 2017) - to use hermeneutics as an analysis method, mainly to analyze al-Qur'an verses that are referred as the foundation of radicalism acts like Khilafah system, Jihad, and tolerance, so that, it can result in the understanding of the problems in more contemporary way. In addition, Jihad should not only understood as a war but also as preaching earnestly (dawah) to create something superior.

\section{REFERENCES}

Abdurrahman, Moeslim. (2005). Islam yang Memihak. Yogyakarta: LKiS.

Al-Asymawi, Muhammad Said. (2002). Jihad Melawan Ekstremisme. Yogyakarta: Desantara.

Ali, As'ad Said. (2014). Al-Qaeda Tinjauan Sosial-Politik, Ideologi dan Sepak Terjangnya. Jakarta: LP3ES.

Al-Maududi, Abu al-A'la. (1980). Jihad in Islam. Lahore.

Arif, Syaiful. (2018). Islam, Pancasila, dan Deradikalisasi Meneguhkan Nilai Keindonesiaan. Jakarta: Elex Media Komputindo.

Azra, Azyumardi. (2016). Tranformasi Politik Islam Radikalisme, Khilafatisme, dan Demokrasi. Jakarta: Prenadamedia Grup.

Ballantyne, Glenda. (2014). Conversing with Subjects: Applying Paul Ricoeur's Hermeneutics to Pedagogical and Academic Language and Learning Practice, Journal of Academic Language \& Learning, 8(1), 37-47.

Bleicher, Joseph. (1980). Contemporary Hermeneutics: Hermeneutics as Method, Philosophy, and Critique. London: Routledge.

Boy, Pradana. ZTF. (2009). Para Pembela Islam Pertarungan Konservatif dan Progresif di Tubuh Muhammadiyah. Depok: Gramata Publishing. 
Bryman, Alan. (2008). Sosial Research Methods, New York. Oxford: University Press.

Darras, Muhammad Abdullah (eds.). (2017). Jihad, Khilafah, dan Terorisme. Bandung: Mizan \& Maarif Institute.

Devji, Faisal. (2005). Landscape of Jihad Militancy, Morality, Modernity. London, Hurst \& Company.

El Fadl, Khalid Abou. (2003). Speaking in God's Name: Islamic Law, Authority and Women. Oxford: One World.

Esposito, J.L. (1992). The Islamic Threat: Mhyth or Reality?. New York.

Fairclough, Norman. (1995). Media Discourse. New York. St. Martin's Press Inc.

Fairclough, Norman. (2010). Critical Discourse Analysis the Critical Study of Language. Edinburgh. Logman Applied Linguistics.

Fanani, Ahmad Fuad. (2004). Islam Mazhab Kritis Menggagas Keberagamaan Liberatif. Jakarta: Kompas.

Hardwick, Louise. (2016). Paul Ricoeur's Theory of Interpretation Adapted as a Method for Narrative Analysis to Capture the Existential Realities Expreesed in Story from People Living with Multiple Sclerosis, Qualitative Social Work (QSW). Sage Publication.

Hasan, Noorhaidi. (2008). Laskar Jihad Islam, Militansi, dan Pencarian Identitas di Indonesia Pasca-Orde Baru. Jakarta: LP3ES-KITLV.

Hikam, A.S. (2016). Deradikalisasi Peran Masyarakat Sipil Indonesia Membendung Radikalisme. Jakarta: Kompas.

Littlejohn, Stephen W. dan Foss, Karen, A. (2009). Encyclopedia of Communication Theory 1. London: Sage Publications.

Lubis, Akhyar Yusuf. (2014). Teori dan Metodologi Ilmu Pengetahuan Sosial Budaya Kontemporer. Jakarta: Rajawali Press.

Mubarak, Muhammad Zaki. (2007). Genealogi Islam Radikal di Indonesia: Gerakan, Pemikiran dan Prospek Demokrasi. Jakarta: LP3ES.

Nashir, Haedar. (2006). Meneguhkan Ideologi Gerakan Muhammadiyah. Yogyakarta: Suara Muhammadiyah.

Nashir, Haedar. (2014). Memahami Ideologi Muhammadiyah. Yogyakarta: Suara Muhammadiyah.

Nathan, K.S. dan Kamali, Mohammad Hasyim (eds.) (2005). Islam in Southeast Asia: Political, Social and Strategic Challenges for the 21st Century. Singapore, Institute of Southeast Asian Studies.

Radford, Garry P. (2005). On The Philosophy of Communication. Belmont: Wadswoth.

Rahman, Taufiqur. (2016), The Trajectory of The Discourse of Jihad in Indonesia. Journal of Social and Relegion1(2), 160-179.

Ricoeur, Paul. (2006). Hermeneutika Ilmu Sosial, (Muhammad Syukri). Yogyakarta: Kreasi Wacana.

Roy, Oliver. (2004). Globalised Islam The Search for A New Ummah. London: C.Hurst \& Co. (Publisher) Ltd.

Santoso, Budi dan Sjuchro, Dian Wardiana. (2019). Is Hizb ut-Tahrir Indonesia Part of Islamic Revival? Journal Komunikator, 11(1), 75-80.

Thompson, John. B. (2003). Analisis Ideologi: Kritik Wacana Ideologi-ideologi Dunia (Haqqul Yakin). Yogyakarta: IRCiSoD. 